Article

\title{
How Do Employees Respond to the CSR Initiatives of their Organizations: Empirical Evidence from Developing Countries
}

\author{
Mariam Farooq ${ }^{1}$, Omer Farooq ${ }^{2, *}$ and Walid Cheffi ${ }^{2}$ \\ 1 Department of Business Adminstration, IQRA University, Karachi 75500, Pakistan; \\ farooqmariam82@gmail.com \\ 2 College of Business and Economics, UAE University, Al Ain, UAE; w.cheffi@uaeu.ac.ae \\ * Correspondence: omer@uaeu.ac.ae
}

Received: 18 March 2019; Accepted: 30 April 2019; Published: 8 May 2019

\begin{abstract}
This research presents a new perspective of social exchange to explain the employee responses to corporate social responsibility (CSR) activities of their organizations. In particular, the current study aims to explore the social exchange based mediation mechanism between CSR actions and employee turnover intentions. Considering this theory, we propose that organizational trust is the primary outcome of CSR, which in turn influences the affective organizational commitment (AOC) and reduces the turnover intentions (TOI) of employees. Moreover, we posit that different types of CSR actions have different effects on employees due to their relative importance. To test the suggested research model, we analyzed the data collected on 304 employees working in the Star hotel in South Asia. Results of the study demonstrate the organizational trust to be a mediator between CSR and AOC and that CSR negatively impacts the turnover intentions of employees through the mediation of trust and AOC. Moreover, the results show the relevance of examining the disaggregated effects of different types of CSR actions on employees' turnover intention. The study concludes with implications for future research and for policy-makers.
\end{abstract}

Keywords: corporate social responsibility; social exchange; organizational trust; affective organizational commitment

\section{Introduction}

As corporate social responsibility (CSR) practices have become widespread in many firms and companies are spending billions of dollars on such activities, it is important to investigate how they affect the internal and external stakeholders of organizations. However, most of the CSR research focuses mostly on external stakeholders (consumers) and financial performance. The research dedicated to internal stakeholders has remained largely neglected [1]. For instance, many studies have examined the effects of CSR on corporate financial performance [2-4], consumers [5-7], and corporate reputation [8,9]. However, employees who play a central role in the performance of firms are largely ignored in CSR literature [1]. It is reported that less than four per cent of relevant studies have focused on employees as the unit of analysis [10].

The current study is an attempt to address this gap by examining how employees' perceptions of the firm's CSR initiatives influence their attitudes and behaviors.

The literature review reveals a lack of empirical studies on the influence of a firm's involvement in CSR practices on employee attitudes and behavior at work [10-13]. This is particularly the case for developing economies [13,14]. Recent studies have established a positive link between perceived CSR and employees' outcomes such as turnover intentions (TOI) $[15,16]$, different forms organizational 
citizen behavior [17-19], and green behavior [20]. The majority of these studies have taken the social identity framework in to consideration [21-25]. However, the current study emphasizes that there are several underpinning mechanisms that can explain the link between CSR and employee behaviors such as turnover intentions (TOI). Adopting these mechanisms should provide a better understanding of the process. In the current study, we bridge this gap by using social exchange theory to explain the phenomenon of the CSR-Employee relationship. We argue that theoretical framework of social exchange theory holds equal or more potential to explain the link between CSR and employee behavior as it is one of the dominant paradigms for the explanation and understanding of the employees as well as their organization [26]. The current study argues that CSR constitutes an inbuilt ability to induce a social exchange mechanism between employees and their company. Employees perceive CSR actions as voluntary investments by the company towards their welfare and in return they feel obliged to reciprocate these benevolent actions with favorable attitudes and behaviors.

Moreover, most of the earlier research mentioned above has examined the direct effect of CSR on employee TOI. The mechanism through which this employee behavior is developed still needs to be explained $[10,14]$. In the current study, we attempt to bridge this gap by examining the effect of CSR on employee behaviors such TOI through the mediation of organizational trust, having social exchange theory as the theoretical framework. The study also investigates the outcomes of the CSR actions comprehensively, by looking at its impact on TOI of employees.

The extant research has examined the aggregated effect of a company's CSR actions. In contrast, this current study tries to get insights of how different types of company CSR initiatives can influence the employees. It is suggested that different types of CSR activities influence employee behavior differently as some of the employees are self-focused while some are focused differently. These individual effects have not been studied previously. This will be helpful for the companies to formulate their CSR strategies accordingly.

Last but not least, most of the earlier studies have been conducted in industrialized nations while the focus of the current study is developing countries, as the data has been collected from the employees of Star hotel in South Asian countries. This part of the world is different from the civilized world in terms of its social, economic, and cultural environment [27]. This will be an expansion of boundary conditions of the earlier studies.

We rely on the four dimensional concept of CSR presented by Farooq, et al. [28] which has been extensively used by many researchers [17,28-35]. As mentioned earlier, Farooq et al (2014a)'s model is comprised of four dimensions: (i) Societal CSR that describes the firm's initiatives taken for the overall support and welfare of the community such as health programs, educational activities, donations, charities, etc. [36]; (ii) internal CSR is the actions of firms for the wellbeing of its employees [17] such as job security, safety at workplace, etc.; (iii) Environmental CSR includes firm's initiatives to enhance the natural environment's quality [37] such as recycling, environment friendly products, etc.; (iv) Product CSR which takes care of issues like research and development, safety, antitrust disputes, etc. [38].

The paper is structured into five sections. Section 2 begins by reviewing the concept of CSR and chooses an appropriate model for this study. Social exchange theory is introduced, which enables us to identify the main effects of CSR (organizational trust and employees' organizational commitment). Section 3 presents the methodology of the paper where structural equation modeling has been used to estimate the research model. Section 4 has been devoted to the results of the paper. Section 5 discusses the results with reference to the extant literature. Finally, Section 6 concludes the paper and states the research implications.

\section{Theoretical Framework and Hypotheses}

The focus of the study is to examine the relationship between CSR and turnover intention via the mediation of trust and affective organizational commitment (AOC). It has been suggested that internal CSR, which is directly relevant to employees, induces social exchange process directly while the other three dimensions of CSR i.e. community, consumer, and environment, indirectly induce the social 
exchange. Considering the social exchange framework, organizational trust is the direct outcome of the CSR initiatives that a firm takes. It then affects the AOC which negatively influences the turnover intentions of the employees.

\subsection{CSR Dimensions and Organizational Trust:}

Social Exchange theory (SET) elucidates how a firm's CSR practices and organizational trust influence each other. This framework is the most dominant theatrical framework to understand the comprehensive relationship among both the parties. The rule of reciprocity is the main doctrine of the theory [39]. For instance, if a person is supplying a benefit, the receiver must respond similarly with kindness [40]. Under this framework, an individual offers a certain benefit to some other person voluntarily, which invokes the receiving end to reciprocate by providing some benefit in return as an obligation [41].

When it is about direct or restricted exchange, both the actors benefit each other in direct reciprocity while in the indirect or generalized exchange both the actors benefit each other and then both of them receive the benefit. However the benefit may not be from the same actor. The current study suggests that CSR has the capacity to induce direct as well as indirect social exchange benefits between the firm and the employees; since both the forms of exchange (direct and indirect) are characterized by some reciprocity [39].

On the other hand, when the firm plays role in the welfare of the society, consumers and environment; it tends to invoke an exchange that is indirect between the firm and the employees. Handelman and Arnold [42] suggested that people are not only concerned with their personal wellbeing but that they also play a significant role in the betterment of the broader certain groups within society. As such, hose firms should be considerate towards them as employees are often part of those groups too. This induces the employees to reciprocate the firm's actions that take care of the welfare of the society, consumers, and the environment.

The first outcome of social exchange relationships is the trust that is developed between the both sides [43]. Also, trust has been identified as an important consequence of favorable social exchange [44]. Furthermore, Cook, Cheshire, Rice and Nakagawa [39] indicated trust to be the pivotal point on which social exchange between the parties revolve. Hence it is proposed that:

Hypothesis 1: Employee perceptions of internal CSR, societal CSR, environmental CSR and product CSR positively influence organizational trust.

\subsection{The Impact of CSR on AOC Mediated by Organizational Trust}

In addition to trust, the literature also suggested organizational commitment to be an important outcome of the social exchange process. Theorists of social exchange suggest that employees that trust firms turn out to support the employer [45]. It turns out that trust is one of the essential conditions for this kind of commitment [46]. Blau [46] further noticed that establishment of exchange relations includes making an investment constituting a commitment to the other party. In order to reciprocate, the social exchange requires trust; the initial condition is to prove oneself to be trustworthy. This is done by the firms' CSR initiatives between the employees and the firms where organizational commitment and organizational trust turn out to be the potential outcomes. In the whole process organizational trust is the first outcome, influencing the employee commitment. This argument has been backed by several researchers revealing organizational trust to be the strong predictor of organizational commitment [28,47-49].

Hypothesis 2a: Organizational trust positively influences the AOC.

Hypothesis 2b: Organizational trust plays its role as a mediator between CSR and AOC. 


\subsection{The Impact of CSR on Turnover Intentions Mediated by Organizational Trust and AOC}

The current study further proposes that employees of a firm that is socially responsible have low turnover intentions based on the benevolent character of the organization as well as the perceived organizational support. The earlier research indicated the successful exchange relationships to reduce the turnover intentions of employees [50,51]. Since the CSR activities of a firm lead to successful social exchanges between a firm and its employees, it is expected that a firm's CSR activities may reduce the turnover intentions of the employees. This effect may not be direct as it appears to be mediated by organizational commitment and organizational trust. Both these factors have been concluded to be the antecedent of the turnover intentions in several studies [52]. Aryee, Budhwar and Chen [43] has found a significant negative relationship between organizational trust and the turnover intentions. Similarly there are several studies concluding that commitment is negatively associated with employee turnover intentions [53,54].

Accordingly, we proposed that:

Hypothesis 3a: Organizational trust and AOC negatively affect turnover intentions.

Hypothesis 3b: The four dimensions of CSR negatively influences turnover intentions through the double mediation of organizational trust and AOC.

The relationships and hypotheses presented lead to the model in Figure 1.

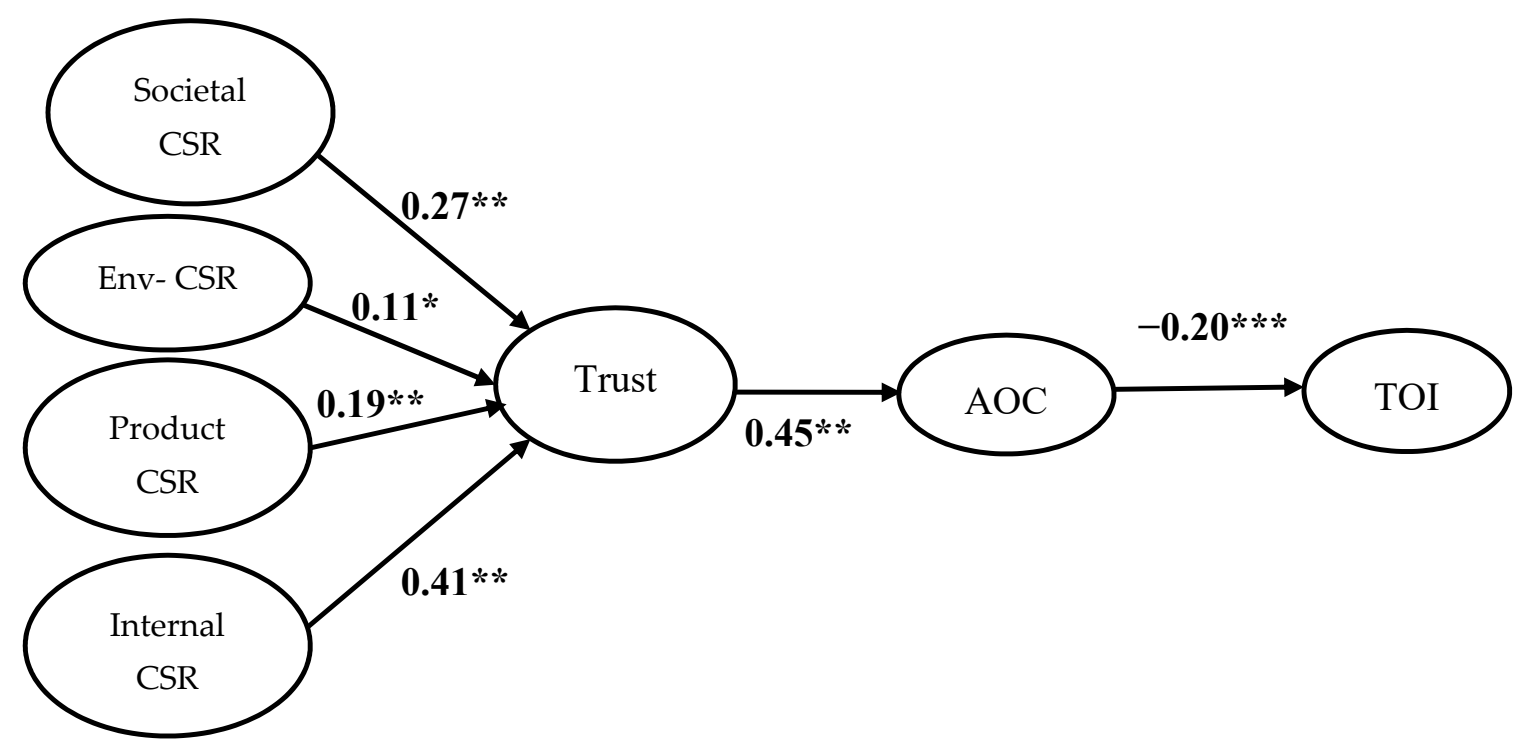

Figure 1. Hypothesized Research Model. AOC: Affective Organizational Commitment; TOI: Turnover Intentions; Values given on the paths are standardized regression coefficients. Values denoted with $(* * *)$ are significant at 0.001 ; Values denoted with $\left(^{* *}\right)$ are significant at 0.01 .

\section{Method}

\subsection{Sample and Procedure}

For the data collection authors assigned the data collection tasks to their students enrolled in MBA programs [55]. These students obtained appointments from the employees. On the date of appointment, students physically visited the organizations and collected data from the employees of Star hotels in South Asia. The data were collected on a self-reporting questionnaire using the paper-pencil format. The respondents were given the questionnaire with a cover letter describing the purpose of the study, instructions to fill in the questionnaire, and anonymity and confidentiality assurances. We received 
336 useable responses, whereas in the follow-up round the figure dropped to 304 useable responses. Forty-seven MBA students and two university professors assisted in the data collection.

We focused on the employees of the Star hotel in South Asia. This choice is motivated by the high turnover of employees in this industry. According to the US Bureau of Labor Statistics [56], the turnover rate in the hospitality sector is the highest rate amongst all industries. In line with Rupp, Ganapathi, Aguilera, and Williams [57], we selected the lower management and/or non-managerial employees for the data collection. Among the 304 employees, there were $72.7 \%$ male participants. In the age classification, it was found that the respondents belonged to different age groups (18-29 years $=42.3 \%$; $30-40$ years $=42.4 \%$; $41-55$ years $=14.8 \%$ ). Regarding the qualification, majority of the respondents had earned a bachelor's degree (46.4\%). $28 \%$ of the respondents had a master's degree and $25.7 \%$ had a high school education. The majority of the respondents were related to non-management $(71.7 \%)$. The average tenure of these employees was 5.96, which ranged from 1-19 years.

\subsection{Measures}

A CSR (multidimensional) measure was adopted from Farooq, Payaud, Merunka and Valette-Florence [28] which contained 16 items. Example items are "Our company gives adequate contributions to charities (Societal CSR)", "Our company makes investments to create a better life for future generations (environmental CSR)", "Our company policies encourage the employees to develop their skills and careers (Internal CSR)" and "Our company protects consumer rights beyond the legal requirements (Product CSR)".

Organizational trust was measured by a three-item scale adopted from Pivato [58].

$A O C$ was measured by five items adopted from Meyer et al.'s [54].

Turnover intentions were measured by five items of Khatri et al. [27]. All items were managed at seven-point Likert scales ( $1=$ "Strongly disagree" to $7=$ "Strongly agree").

\section{Results}

\subsection{Assessing the Adequacy of Measurement Instruments (Confirmatory Factor Analysis)}

Since all the measuring instruments were adopted from Western studies, it was necessary to evaluate their validity in the South Asian context [59-61]. We performed a confirmatory factor analysis (CFA) to assess the convergent and discriminant validity of all the instruments of the study. We developed a measurement structure of all the variables and covariated them in single model. This allowed us to assess the cross loadings there were if any and permitted us to calculate the discriminant validity of the measures. We used MPlus 7 to test the measurement model as well as hypothesized model. Seven-factor model produced good fit with data $\left(X^{2}=536.81\right.$; $\mathrm{Df}=356$; $\mathrm{X}^{2} / \mathrm{Df}=1.51 ; \mathrm{CFI}=0.98 ; \mathrm{TLI}=0.97 ; \mathrm{RMSEA}=0.04 ; \mathrm{SRMR}=0.03$ ). On the other hand, a single factor model in which all factors were loaded to one factor produced a poor fit with data. In a seven-factor model, the standardized factor loading was higher than 0.50 [62].

In addition, we also analyzed the convergent and discriminate validity of all seven latent variables using the average variance extracted (AVE) method suggested by Fornell \& Larcker, [63]. The values of the AVE that were greater than the recommended value of 0.50 are presented in Table 1 [63]. Thus, all constructs have a high convergent validity. For assessing discriminant validity, we used a factor-based procedure [63]. This is the most rigorous and powerful method as it has resolved the problems of the difference of the chi-square method [63]. By using this procedure, we concluded that these constructs are different from each other because the square root of average variance extracted by each construct was greater than their following correlations (see the Table 2). 
Table 1. Convergent validity and reliability.

\begin{tabular}{cccc}
\hline Latent Variables & Convergent Validity & Cronbach's Alpha & Joreskög's Rhô. \\
\hline Societal CSR & 0.55 & 0.77 & 0.78 \\
Environmental CSR & 0.77 & 0.93 & 0.93 \\
Product CSR & 0.78 & 0.91 & 0.91 \\
Internal CSR & 0.79 & 0.96 & 0.96 \\
Trust & 0.70 & 0.87 & 0.87 \\
AOC & 0.69 & 0.91 & 0.92 \\
TOI & 0.80 & 0.95 & 0.95 \\
\hline
\end{tabular}

Table 2. Descriptive Statistics Correlation Matrix and Test of Discriminant Validity.

\begin{tabular}{cccccccccc}
\hline Latent Variables & Mean & SD & $\mathbf{1}$ & $\mathbf{2}$ & $\mathbf{3}$ & $\mathbf{4}$ & $\mathbf{5}$ & $\mathbf{6}$ & $\mathbf{7}$ \\
\hline Societal CSR & 3.61 & 1.23 & 0.74 & & & & & & \\
Env CSR & 3.36 & 1.35 & $0.13^{*}$ & 0.74 & & & & & \\
Product CSR & 5.16 & 1.58 & $0.14^{*}$ & -0.03 & 0.88 & & & & \\
Internal CSR & 4.19 & 1.19 & $0.37^{* *}$ & $0.22^{* *}$ & 0.06 & 0.89 & & & \\
Trust & 4.22 & 1.11 & $0.39^{* *}$ & $0.21^{* *}$ & $0.24^{* *}$ & $0.53 * *$ & 0.84 & & \\
AOC & 4.07 & 1.29 & $0.23^{* *}$ & $0.19^{* *}$ & 0.08 & $0.34^{* *}$ & $0.41^{* *}$ & 0.83 & \\
Turnover & 4.30 & 1.84 & $-0.14^{*}$ & -0.08 & -0.08 & -0.10 & $-0.12^{*}$ & $-0.18^{* *}$ & 0.89 \\
\hline
\end{tabular}

Notes: Values on the diagonal represent the square root of convergent validity. Values in the columns are the correlations between two constructs. Values denoted with $\left(^{*}\right)$ are significant at 0.05 and with $\left(^{* *}\right)$ are significant at 0.01 .

In addition to measurement adequacy and validity, we also examined the internal reliability and consistency of our measures. The values of Cronbach Alpha values [64] and Joreskog rho (Table 1) were all sufficiently greater than the recommended value of 0.7 [65]. Table 2 also presents the means, standard deviation and correlations of all the studied variables.

\subsection{Model Testing}

The hypotheses were tested with the help of structural equation modeling using Mplus version 7. A hypothesized research model produced a very good fit with the data $\left(X^{2}=551.30 ; D f=365\right.$; $\mathrm{X}^{2} / \mathrm{Df}=1.51 ; \mathrm{CFI}=0.98 ; \mathrm{TLI}=0.97 ; \mathrm{RMSEA}=0.04 ; \mathrm{SRMR}=0.05$ ).

The direct effects obtained from this model are given in Table 3. The four dimensions of CSR appeared as strong predictors of organizational trust. Internal CSR had the strongest effect of 0.41 at a 0.001 level of significance. Societal CSR had an effect of 0.27 at a 0.001 significance level, whereas product CSR had an effect of 0.19 at 0.001 level of significance based on organizational trust. On the other hand, environmental CSR has a weaker relationship with organizational trust ( 0.11 at 0.05 significance level). Therefore, our hypothesis- 1 was fully supported by the data. However, hypothesis $2 \mathrm{a}$ and hypothesis 3 a were fully supported by the data. Trust had a strong positive influence of 0.45 at 0.001 on AOC. It was also found that AOC negatively impacted the employees' turnover intentions ( -0.20 at 0.001$)$.

Table 3. Direct Effects, Standardized regression estimates obtained from the hypothesized model.

\begin{tabular}{cccc}
\hline Independent Variables & Trust & AOC & TOI \\
\hline Societal CSR & $0.27(0.000)$ & - & - \\
Environmental CSR & $0.11(0.044)$ & - & - \\
Product CSR & $0.19(0.000)$ & - & - \\
Internal CSR & $0.41(0.000)$ & - & - \\
Trust & - & $0.45(0.000)$ & $-0.20(0.001)$ \\
AOC & - & - &
\end{tabular}

Notes: -Level of significance is given in brackets; - Values in the column are standardized regression weights; - Trust, $\mathrm{AOC}$ and TOI as dependent variables. 


\subsubsection{Mediation of Trust between CSR Dimensions and AOC}

We examined the mediation of trust between CSR dimensions and AOC in MPlus by using a structural equation modeling technique [66]. MPlus has the advantage over the other statistical tools because it provides direct and indirect effects simultaneously. We also calculated the direct effects of independent variables on the dependent variable AOC after partialling out the effect of the mediator (C-prim Path). According to recent research, mediation is indicated when both of the independent to moderator and moderator to independent path coefficients are significant [66].

The results of mediation analysis are given in the Table 4 . Indirect effects of societal CSR, product CSR, and internal CSR on AOC were found significant which shows the mediation of trust between these three dimensions of CSR and AOC. Direct effects after partialling out the effect of mediator ( $C^{\prime}$ path) were significant only for the internal CSR, therefore, organizational trust partially mediates between internal CSR and AOC while fully mediating for the other two dimensions. Internal CSR had some direct effect on AOC (54\%) but $46 \%$ of the total effect of internal CSR on AOC was through the mediation of organizational trust.

Table 4. Mediation of Trust between CSR dimensions and AOC.

\begin{tabular}{ccccc}
\hline $\begin{array}{c}\text { Independent } \\
\text { Variables }\end{array}$ & Indirect Effects ${ }^{1}$ & Direct Effect ${ }^{2}$ & $\begin{array}{c}\text { Proportion of } \\
\text { Mediation }\end{array}$ & Remarks \\
\hline AB Path & $\mathbf{C}^{\prime}$ Path & AB/AB+ CC' & \\
\hline Societal CSR & $0.09(0.003)$ & $0.02(0.75)$ & - & Full Mediation \\
Product CSR & $0.06(0.006)$ & $0.02(0.72)$ & - & Full Mediation \\
Internal CSR & $0.13(0.001)$ & $0.15(0.04)$ & $0.46(46 \%)$ & Partial Mediation \\
Environmental & $0.03(0.084)$ & $0.09(0.12)$ & - & No mediation \\
CSR & & & & \\
\hline
\end{tabular}

Notes: -Dependent Variables: AOC; ${ }^{1} \mathrm{AB}$ path represents indirect effect of CSR dimensions through the mediation of trust; Values in column are standardized indirect effect obtained from the hypothesized model; ${ }^{2} \mathrm{CC}^{\prime}$ path represents direct effects of CSR dimension of AOC after partialling out the effects of mediator; Values in column are standardized regression weights obtained from the hypothesized model.

\subsubsection{Mediation of Trust and AOC between CSR Dimensions and Turnover Intentions}

Using the same procedure, we examined the double mediation of trust and AOC between CSR dimensions and turnover intentions in structural equation modeling using Mplus 7. It is important to indicate that it is not a multi-mediation as we did not examine two alternate paths from the independent to dependent variable [66]. We examined the single path where two mediators were placed in a row according to a theoretical order. We did not include the environmental CSR in this analysis because we found it to have an insignificant indirect effect on AOC. Results are given in Table 5. Indirect effects of all three dimensions of CSR were significant which shows that three dimensions of CSR negatively affect the turnover intentions through trust and AOC. Only societal CSR had a direct negative effect (after partialling out the effect of mediators) on turnover intentions which show the partial mediation in case of societal CSR and full mediation in the case of product CSR and internal CSR. These results revealed that the indirect effect of internal CSR on TOI via trust and AOC was significant at the 0.05 level whereas the indirect effect of other two dimensions (societal and product) was significant at the 0.10 level. 
Table 5. Double Mediation of Trust and AOC between CSR dimensions and Turnover intentions.

\begin{tabular}{|c|c|c|c|c|}
\hline $\begin{array}{l}\text { Independent } \\
\text { Variables }\end{array}$ & Indirect Effects ${ }^{1}$ & Direct Effect $^{2}$ & $\begin{array}{l}\text { Proportion of } \\
\text { Mediation }\end{array}$ & Remarks \\
\hline & ABC Path & DC' Path & $\mathrm{ABC} / \mathrm{ABC}+\mathrm{DC}^{\prime}$ & \\
\hline Societal CSR & $-0.01(0.06)$ & $-0.15(0.05)$ & $0.06(6 \%)$ & Partial Mediation \\
\hline Product CSR & $-0.01(0.07)$ & $-0.05(0.45)$ & - & Full Mediation \\
\hline Internal CSR & $-0.02(0.047)$ & $0.02(0.76)$ & - & Full Mediation \\
\hline \multicolumn{5}{|c|}{$\begin{array}{l}\text { Notes: -Dependent Variables: Turnover intentions; }{ }^{1} \mathrm{ABC} \text { Path represents the indirect effect of CSR dimensions on } \\
\text { turnover intentions through the double mediation of Trust and AOC; Values in column are a standardized indirect } \\
\text { effect obtained from the hypothesized model; these paths represent double mediation (It is not a multi-mediation); } \\
{ }^{2} \mathrm{DC} \mathrm{C}^{\prime} \text { path represents the direct effects of CSR dimensions after partialling out the effect of the trust and AOC } \\
\text { mediators; Values in column are standardized regression weights obtained from the hypothesized model. }\end{array}$} \\
\hline
\end{tabular}

\section{Discussion}

In contrast to the earlier studies, the current research relies on the social exchange perspective of employees in response to their firm's CSR activities. Moreover, the study also established that organizational trust is the first outcome of the CSR activities while AOC is the second order outcome.

Four components of the multidimensional CSR including the societal CSR, product CSR, environmental CSR and internal CSR have positive impacts on the organizational trust which enhances the worthiness of the firm. The CSR activities of a firm indicate it to be a fair, benevolent and concerned entity for its employees. Social exchange theory stresses that employee perceptions about their firms to be benevolent, fair and concerned compel them to reciprocate which ultimately develops in them an organizational trust [66]. These actions are also a strong indicator of generalized justice which again is a strong predictor of organizational trust [67].

Internal CSR has been proven to be the strongest predictor of organizational trust. The results have been consistent with the literature of high performance work systems (HPWS). This literature has emphasized using human resource management practices that motivate the employees to be a source of competitive advantage [68]. Since the literature demonstrates the ability of HPWS to improve the quality of labor and firm performance [69], our findings also consolidate the same literature, demonstrating a strong relationship between the organizational trust and internal CSR of the firm building strong employee commitment.

The results of the study also show a strong positive effect of societal CSR dimensions on organizational trust. This depicts the CSR actions related to the development of community, donations, charities, and contribution to social issues to be perceived positively by the people in South Asia. That shows CSR actions of the firms are not only important but that this is also vital to understanding how the employees reciprocate to these organizational actions. With the perspective of indirect exchange, they reciprocate in term of trust, commitment and lower turnover intentions.

Our findings also revealed that the interviewed employees in Pakistan primarily value the societal CSR as compared to the other facets of CSR while developing their trust. The possible reason of this finding may be the lower organizational community related practices in the region of South Asia as compared to the Western context [70].

Product CSR also has a positive effect on organizational trust, which shows that the company employing CSR has a greater ability to serve and satisfy its customer than others. This type of ability of a firm has been identified as an antecedent of organizational trust [71,72].

Similarly environmental CSR also had a relationship with the organizational trust. People in Pakistan are also aware about the organizational actions toward the environment. They develop their trust in the organization when they perceive environmental CSR. In comparison to the effect of other CSR actions, the effect of environmental CSR was weaker. South Asian employees may be less sensitive towards the environmental impact of their firm's operations. The low response in turn may be caused due to the economic conditions in South Asia where approximately $24 \%$ of the population lives below the poverty line [73]. As such, employees may give lesser significance to environmental issues as 
compared to economic ones. This was empirically proven in a study conducted by Burton, et al. [74], where Hong Kong's students were more inclined towards economic responsibilities as compared to non-economic responsibilities of the firms. The case was completely different for U.S students where the opposite was found to be true.

The effect of internal CSR on organizational trust was also found to be higher as compared to the rest of the three CSR dimensions. The reason for this can be that it is directly related to the employees whereas the other dimensions are focused on others. It is because the self vs. other phenomena is dominant in collectivist societies such as South Asia. In such cultures, there is no doubt harmony within the groups, however the overall society is considered to be a non-sharing and disharmonious one [75]. As a result, employees turn out to be more concerned with the firms CSR activities that are directly related to them rather than activities concerning the environmental, societal and product CSR practices of the firm.

Moreover, trust was concluded to be a significant determinant of AOC, in line with several other studies depicting organizational trust [43]. Further effects of the CSR dimensions were studied via mediation of trust on AOC. Full mediation was there between the societal CSR and AOC and between the products related CSR and AOC. This clearly shows trust to be the first and foremost outcome of these couple of CSR dimensions. This enhances the trustworthiness of the firms which induced employees to remain committed to their firms. Unlike these two dimensions, trust has been seen to be partially mediating between the internal CSR and AOC, implying that internal CSR not only contributed to AOC via trust but also influence the same via other means. Moreover, internal CSR and product CSR were concluded to be negatively associated with the turnover intentions of the employees through full mediation of AOC and trust. However, the same (AOC and trust) partially mediate societal CSR and turnover intentions.

This clearly shows that societal CSR has the ability to directly influence the turnover intentions of employees. A reason for this deduced from Aguilera, et al. [76] is that employee perceptions of the external CSR of the firms as a special part of the general justice perceptions and that these perceptions of CSR shape the subsequent attitudes and behaviors of the employees towards their organization. Societal CSR can also be perceived as having an impact on the employee's turnover intentions [77].

\section{Conclusions}

Based on the findings from the data collected from 304 employees working in Star hotels, this paper demonstrates that CSR has a positive influence on employees' attitudes and behaviors. However, CSR may induce these employees' attitudes and behaviors indirectly through the mechanism of social exchange and mediation of employees trust in their organizations. This research also suggests that different kinds of CSR activities influence employees differently. The CSR activities focused on employees themselves have the highest positive impact on their behaviors, which is followed by CSR activities targeted at society and the community. These findings regarding the differential effects of different CSR activities have many implications for managers.

\subsection{Theoretical Contributions}

This research presents an interdisciplinary framework because it applies social psychological theory to understand an organizational phenomenon. We integrate a macro level concept of CSR with micro level variables related to employees. Rupp et al., [57] demonstrate that due to over emphasis on macro level research, the CSR literature is missing a rigorous micro level analysis. This research thus opened a new avenue in the CSR research by highlighting the role of CSR in employee attitudes and behaviors [10].

Moreover, the extant literature has mostly examined the direct effect of CSR on employee behaviors. The mechanism through which employee behavior is developed from CSR still needs to be explained. The findings of the current study demonstrate that CSR activities of the firms induce trust among employees, which in turn influences their intentions and behaviors. By explaining the underpinning 
mechanism, overall implications of the research is significantly enhanced. In so doing, we extend and enrich recent studies that address the influence of firm's involvement in CSR practices on employee attitudes and behavior in the workplace $[13,78,79]$.

As discussed earlier, the results have demonstrated that different types of CSR activities influence the trust of employees and other behaviors differently. On the other hand, the existing research have examined the aggregated effect of a company's CSR actions on employees attitudes and behavior [13]. This research suggest that different types of CSR activities influence employee behavior differently as some of the employees are self-focused while some are focused differently. These individual (disaggregated) effects have not been studied earlier. This will be helpful for the companies to formulate their CSR strategies accordingly.

Last but not least, most of the extant studies have been conducted in industrialized nations while the focus of the current study is the developing countries as the data has been collected from the employees of Star hotels in South Asian countries. This part of the world is at large different from the developed world in terms of social, economic, and cultural environment [27]. This expands the boundary conditions of the earlier studies.

\subsection{Practical Implications}

The results have also significant implications for firm CSR based strategies. It has been concluded that CSR strongly influenced organizational trust, while AOC and turnover intentions focus on the instrumental values of CSR. Employee behavior and attitudes are intangible resources which are rare and valuable and cannot be imitated perfectly with no perfect substitutes [75]. The results of the study imply that CSR develops intangible resources in the firms. Trust and AOC affect the job related factors such as turnover intention which help the organizations in the achievement of competitive advantage [68]. Hence CSR assists in developing a workforce carrying out the firm's business strategy and leading to enhanced business performance [80]. Firms that possess higher CSR practices may develop enhanced productivity because of the reduced absenteeism, motivation and extra role behavior of the employees as well as the reduced turnover intentions. Interestingly, the results also illustrate that the benefits of the corporate contributions towards community are not at all restricted to the management of external stakeholders or external reputation. CSR benefits may be mirrored in the internal stakeholder's (employees) behavior. Last but not least, this study suggests that an organization can get the most from CSR activities when the employees trust its involvement in such activities. Therefore, firms' efforts should be directed towards addressing the levers of trust. This include hearing employees' voices before launching CSR activities, involving the personnel in the deployment of CSR initiatives, and adopting employee-centered marketing.

\subsection{Limitations and Future Research Directions}

While introducing social exchange mechanisms, we use organizational trust to represent the exchange relationships between parties and we did not consider other variables within social exchange relationships such as perceived organizational support and leader-member exchange. Thus, future studies should include other variables within social exchange relationships. In the same vein, since trust is a dynamic psychosocial construct, it might be worthwhile to conduct further research on the evolution of the relationships between CSR, trust and TOI throughout time. The constantly changing organizational environment may affect the relationships portrayed in this study.

Moreover, we did not incorporate moderating conditions that may affect the social exchange mechanism. In particular, future research should consider cultural characteristics of the employees as boundary conditions of such relationships.

We used a convenience sample for the collection of data. Therefore, our sample may not be truly representative of the population. In addition, the data were collected using a cross-sectional design that looked at individual perceptions, which does not allow concluding the causality. Nevertheless, perceptions may be a construct at least as equal as that of 'actual firm behaviors' of which employees 
may not be aware [81]. Therefore, future research can also gain from conducting longitudinal and panel datasets.

Finally, this study focused only on employees in the tourism industry (Star hotels). This choice was motivated by the high turnover of employees in this sector (US Bureau of Labor Statistics, 2017). However, different industries may affect involved parties' perceptions of and attitudes towards CSR activities in different ways [82,83]. Future research should also incorporate other industries, in particular those where the turnover rate is high such as the construction and the professional business services industries.

Author Contributions: Formal analysis, M.F. and O.F.; Funding acquisition, O.F.; Investigation, M.F.; Methodology, M.F.; Project administration, M.F.; Supervision, O.F.; Writing - original draft, M.F., O.F. and W.C.; Writing - review \& editing, Mariam Farooq, M.F., O.F. and W.C.

Funding: This research is partially supported by UAE University, Al Ain-UAE via the Startup grant to corresponding author (Omer Farooq).

Conflicts of Interest: The authors declare no conflict of interest.

\section{Abbreviations}

CSR: Corporate social responsibility; AOC: Affective organizational commitment; TOI: Turnover intentions.

\section{References}

1. Larson, B.V.; Flaherty, K.E.; Zablah, A.R.; Brown, T.J.; Wiener, J.L. Linking cause-related marketing to sales force responses and performance in a direct selling context. J. Acad. Mark. Sci. 2008, 36, 271-277. [CrossRef]

2. Griffin, J.J.; Mahon, J.F. The corporate social performance and corporate financial performance debate. Bus. Soc. 1997, 36, 5. [CrossRef]

3. Orlitzky, M.; Schmidt, F.L.; Rynes, S.L. Corporate social and financial performance: A meta-analysis. Studies 2003, 24, 403-441. [CrossRef]

4. Waddock, S.A.; Graves, S.B. The corporate social performance-financial performance link. Strateg. Manag. J. 1997, 18, 303-319. [CrossRef]

5. Lichtenstein, D.R.; Drumwright, M.E.; Braig, B.M. The effect of corporate social responsibility on customer donations to corporate-supported nonprofits. J. Mark. 2004, 68, 16-32. [CrossRef]

6. Luo, X.; Bhattacharya, C. Corporate social responsibility, customer satisfaction, and market value. J. Mark. 2006, 70, 1-18. [CrossRef]

7. Sen, S.; Bhattacharya, C.; Korschun, D. The role of corporate social responsibility in strengthening multiple stakeholder relationships: A field experiment. J. Acad. Mark. Sci. 2006, 34, 158. [CrossRef]

8. Johnson, H.H. Does it pay to be good? Social responsibility and financial performance. Bus. Horiz. 2003, 46, 34-40. [CrossRef]

9. Porter, M.E.; Kramer, M.R. The competitive advantage of corporate philanthropy. Harv. Bus. Rev. 2002, 80, 56-68.

10. Aguinis, H.; Glavas, A. What we know and don't know about corporate social responsibility: A review and research agenda. J. Manag. 2012, 38, 932-968. [CrossRef]

11. Rodrigo, P.; Arenas, D. Do employees care about CSR programs? A typology of employees according to their attitudes. J. Bus. Ethics 2008, 83, 265-283. [CrossRef]

12. Hansen, S.D.; Dunford, B.B.; Boss, A.D.; Boss, R.W.; Angermeier, I. Corporate social responsibility and the benefits of employee trust: A cross-disciplinary perspective. J. Bus. Ethics 2011, 102, 29-45. [CrossRef]

13. Chaudhary, R.; Chaudhary, R. Demographic factors, personality and entrepreneurial inclination: A study among Indian university students. Educ. Train. 2017, 59, 171-187. [CrossRef]

14. Gharleghi, B.; Afshar Jahanshahi, A.; Nawaser, K. The outcomes of corporate social responsibility to employees: Empirical evidence from a developing country. Sustainability 2018, 10, 698. [CrossRef]

15. Kim, J.S.; Song, H.J.; Lee, C.-K. Effects of corporate social responsibility and internal marketing on organizational commitment and turnover intentions. Int. J. Hosp. Manag. 2016, 55, 25-32. [CrossRef]

16. Ng, T.W.; Yam, K.C.; Aguinis, H. Employee perceptions of corporate social responsibility: Effects on pride, embeddedness, and turnover. Pers. Psychol. 2019, 72, 107-137. [CrossRef] 
17. Farooq, O.; Rupp, D.E.; Farooq, M. The multiple pathways through which internal and external corporate social responsibility influence organizational identification and multifoci outcomes: The moderating role of cultural and social orientations. Acad. Manag. J. 2017, 60, 954-985. [CrossRef]

18. Supanti, D.; Butcher, K. Is corporate social responsibility (CSR) participation the pathway to foster meaningful work and helping behavior for millennials? Int. J. Hosp. Manag. 2019, 77, 8-18. [CrossRef]

19. He, J.; Zhang, H.; Morrison, A.M. The impacts of corporate social responsibility on organization citizenship behavior and task performance in hospitality: A sequential mediation model. Int. J. Contemp. Hosp. Manag. 2019. [CrossRef]

20. Su, L.; Swanson, S.R. Perceived corporate social responsibility's impact on the well-being and supportive green behaviors of hotel employees: The mediating role of the employee-corporate relationship. Tour. Manag. 2019, 72, 437-450. [CrossRef]

21. Brammer, S.; Millington, A.; Rayton, B. The contribution of corporate social responsibility to organizational commitment. Int. J. Hum. Resour. Manag. 2007, 18, 1701-1719. [CrossRef]

22. Peterson, D.K. The relationship between perceptions of corporate citizenship and organizational commitment. Bus. Soc. 2004, 43, 296. [CrossRef]

23. Rego, A.; Leal, S.; Cunha, M.; Faria, J.; Pinho, C. How the Perceptions of Five Dimensions of Corporate Citizenship and Their Inter-Inconsistencies Predict Affective Commitment. J. Bus. Ethics 2010, 94, 107-127. [CrossRef]

24. Stites, J.P.; Michael, J.H. Organizational commitment in manufacturing employees: Relationships with corporate social performance. Bus. Soc. 2011, 50, 50. [CrossRef]

25. Turker, D. How corporate social responsibility influences organizational commitment. J. Bus. Ethics 2008, 89, 189-204. [CrossRef]

26. Brammer, S.; He, H.; Mellahi, K. Corporate social responsibility, employee organizational identification, and creative effort: The moderating impact of corporate ability. Group Organ. Manag. 2015, 40, 323-352. [CrossRef]

27. Khatri, N.; Fern, C.T.; Budhwar, P. Explaining employee turnover in an Asian context. Hum. Resour. Manag. J. 2001, 11, 54-74. [CrossRef]

28. Farooq, O.; Payaud, M.; Merunka, D.; Valette-Florence, P. The Impact of Corporate Social Responsibility on Organizational Commitment: Exploring Multiple Mediation Mechanisms. J. Bus. Ethics 2014, 125, 563-580. [CrossRef]

29. De Roeck, K.; Farooq, O. Corporate social responsibility and ethical leadership: Investigating their interactive effect on employees' socially responsible behaviors. J. Bus. Ethics 2018, 151, 923-939. [CrossRef]

30. Farooq, M.; Farooq, O.; Jasimuddin, S.M. Employees response to corporate social responsibility: Exploring the role of employees' collectivist orientation. Eur. Manag. J. 2014, 32, 916-927. [CrossRef]

31. Farooq, O.; Merunka, D.; Valette-Florence, P. Employees' response to corporate social responsibility: An application of a non linear mixture REBUS approach. In New Perspectives in Partial Least Squares and Related Methods; Springer: Berlin/Heidelberg, Germany, 2013; pp. 257-268.

32. Hameed, I.; Arain, G.; Farooq, O. Identity-Based Trust as a Mediator of the Effects of Organizational Identification on Employee Attitudes: An Empirical Study. Int. J. Manag. 2013, 31, 666-677.

33. Hameed, I.; Riaz, Z.; Arain, G.A.; Farooq, O. How Do Internal and External CSR Affect Employees' Organizational Identification? A Perspective from the Group Engagement Model. Front. Psychol. 2016, 7, 1-13. [CrossRef] [PubMed]

34. Jones, D.A.; Farooq, O.; De Roeck, K.; Farooq, M. Do Attributed Motives Moderate the Effect of Corporate Social Responsibility on Employees' OCB? Acad. Manag. Ann. Meet. Proc. 2018, 17899. [CrossRef]

35. Farooq, O.; Farooq, M.; Reynaud, E. Does Employees' Participation in Decision Making Increase the level of Corporate Social and Environmental Sustainability? An Investigation in South Asia. Sustainability 2019, 11, 511. [CrossRef]

36. Wang, H.; Tong, L.; Takeuchi, R.; George, G. Corporate Social Responsibility: An Overview and New Research Directions: Thematic Issue on Corporate Social Responsibility; Academy of Management: Briarcliff Manor, NY, USA, 2016.

37. McWilliams, A.; Siegel, D.S.; Wright, P.M. Corporate social responsibility: Strategic implications. J. Manag. Stud. 2006, 43, 1-18. [CrossRef] 
38. Peloza, J.; Ye, C.; Montford, W.J. When companies do good, are their products good for you? How corporate social responsibility creates a health halo. J. Public Policy Mark. 2015, 34, 19-31. [CrossRef]

39. Cook, K.S.; Cheshire, C.; Rice, E.R.; Nakagawa, S. Social Exchange Theory; Springer: Berlin/Heidelberg, Germany, 2013.

40. Ekeh, P.P. Social Exchange Theory: The Two Traditions; Heinemann: London, UK, 1974.

41. Whitener, E.M.; Brodt, S.E.; Korsgaard, M.A.; Werner, J.M. Managers as initiators of trust: An exchange relationship framework for understanding managerial trustworthy behavior. Acad. Manag. Rev. 1998, 23, 513-530. [CrossRef]

42. Handelman, J.M.; Arnold, S.J. The role of marketing actions with a social dimension: Appeals to the institutional environment. J. Mark. 1999, 63, 33-48. [CrossRef]

43. Aryee, S.; Budhwar, P.S.; Chen, Z.X. Trust as a mediator of the relationship between organizational justice and work outcomes: Test of a social exchange model. J. Organ. Behav. 2002, 23, 267-285. [CrossRef]

44. Ertürk, A. Influences of HR Practices, Social Exchange, and Trust on Turnover Intentions of Public IT Professionals. Public Pers. Manag. 2014, 43, 140-175. [CrossRef]

45. Eisenberger, R.; Huntington, R.; Hutchison, S.; Sowa, D. Perceived organizational support. J. Appl. Psychol. 1986, 71, 500. [CrossRef]

46. Blau, P.M. Exchange and Power in Social Life; Transaction Publishers: Piscataway Township, NJ, USA, 1964.

47. Utami, A.F.; Bangun, Y.R.; Lantu, D.C. Understanding the Role of Emotional Intelligence and Trust to the Relationship between Organizational Politics and Organizational Commitment. Procedia Soc. Behav. Sci. 2014, 115, 378-386. [CrossRef]

48. Jain, P.; Duggal, T.; Ansari, A.H. Examining the mediating effect of trust and psychological well-being on transformational leadership and organizational commitment. Benchmark. Int. J. 2019. [CrossRef]

49. Liggans, G.; Attoh, P.A.; Gong, T.; Chase, T.; Russell, M.B.; Clark, P.W. Military Veterans in Federal Agencies: Organizational Inclusion, Human Resource Practices, and Trust in Leadership as Predictors of Organizational Commitment. Public Pers. Manag. 2019. [CrossRef]

50. Sheehan, C.; Tham, T.L.; Holland, P.; Cooper, B. Psychological contract fulfilment, engagement and nurse professional turnover intention. Int. J. Manpow. 2019. [CrossRef]

51. Rutishauser, L.; Sender, A. Effect of Team-Member Exchange on Turnover Intention: A Cross-Cultural Perspective on a Selected Aspect of Employee Engagement. Int. Stud. Manag. Organ. 2019, 49, 43-62. [CrossRef]

52. Meyer, J.P.; Stanley, D.J.; Herscovitch, L.; Topolnytsky, L. Affective, Continuance, and Normative Commitment to the Organization: A Meta-analysis of Antecedents, Correlates, and Consequences. J. Vocat. Behav. 2002, 61, 20-52. [CrossRef]

53. Konovsky, M.A.; Brockner, J. Managing Victim and Survivor Layoff Reactions: A Procedural Justice Perspective; Lawrence Erlbaum Associates, Inc.: Hillsdale, NJ, USA, 1993.

54. Meyer, J.P.; Allen, N.J.; Smith, C.A. Commitment to Organizations and Occupations: Extension and Test of a Three-Component Conceptualization. J. Appl. Psychol. 1993, 78, 538-551. [CrossRef]

55. Arshad, M.; Farooq, O.; Farooq, M. The effect of intrinsic and extrinsic factors on entrepreneurial intentions: The moderating role of collectivist orientation. Manag. Decis. 2018. [CrossRef]

56. Labor, U. US Bureau of Labor Statistics, 2017. Available online: https://www.bls.gov/ (accessed on 4 March 2018).

57. Rupp, D.E.; Ganapathi, J.; Aguilera, R.V.; Williams, C.A. Employee reactions to corporate social responsibility: An organizational justice framework. J. Organ. Behav. 2006, 27, 537-543. [CrossRef]

58. Pivato, S.; Misani, N.; Tencati, A. The impact of corporate social responsibility on consumer trust: The case of organic food. Bus. Ethics A Eur. Rev. 2008, 17, 3-12. [CrossRef]

59. Arshad, M.; Farooq, O.; Afzal, S. The role of entrepreneurship education in developing a passion for business. Glob. Bus. Organ. Excell. 2018, 38, 15-21. [CrossRef]

60. Arshad, M.; Farooq, O.; Sultana, N.; Farooq, M. Determinants of individuals' entrepreneurial intentions: A gender-comparative study. Career Dev. Int. 2016, 21, 318-339. [CrossRef]

61. Dost, M.; Arshad, M.; Afsar, B. The Influence of Entrepreneurial Orientation on Types of Process Innovation Capabilities and Moderating Role of Social Capital. Entrep. Res. J. 2018, 8, 1-15. [CrossRef]

62. Kline. Principles and Practice of Structural Equation Modeling; Guilford Press: New York, NY, USA, 2011. 
63. Fornell, C.; Larcker, D.F. Structural equation models with unobservable variables and measurement error: Algebra and statistics. J. Mark. Res. 1981, 18, 382-388. [CrossRef]

64. Cronbach, L.J. Coefficient alpha and the internal structure of tests. Psychometrika 1951, 16, 297-334. [CrossRef]

65. Nunnally, J.C. Psychometric Theory, 2nd ed.; McGraw-Hill: New York, NY, USA, 1978.

66. Iacobucci, D.; Saldanha, N.; Deng, X. A meditation on mediation: Evidence that structural equations models perform better than regressions. J. Consum. Psychol. 2007, 17, 139-153. [CrossRef]

67. Cohen-Charash, Y.; Spector, P.E. The Role of Justice in Organizations: A Meta-Analysis* 1. Organ. Behav. Hum. Decis. Process. 2001, 86, 278-321. [CrossRef]

68. Datta, D.K.; Guthrie, J.P.; Wright, P.M. Human resource management and labor productivity: Does industry matter? Acad. Manag. J. 2005, 48, 135-145. [CrossRef]

69. Huselid, M.A. The Impact of Human Resource Management Practices on Turnover, Productivity, and Corporate Financial Performance. Acad. Manag. J. 1995, 38, 635-672.

70. Krishnamurthy, S.; Chew, W.; Soh, T.; Luo, W. (Eds.) Corporate Social Responsibility and Public Relations, Perceptions and Practices in Singapore; Oxford University Press: New York, NY, USA, 2007.

71. Barber, B. The Logic and Limits of Trust; Rutgers University Press: New Brunswick, NJ, USA, 1983.

72. Blomqvist, K. The many faces of trust. Scand. J. Manag. 1997, 13, 271-286. [CrossRef]

73. CIA. The World Fact Book. Available online: https://www.cia.gov/library/publications/the-world-factbook/ geos/pk (accessed on 3 March 2018).

74. Burton, B.K.; Farh, J.-L.; Hegarty, W.H. A cross-cultural comparison of corporate social responsibility orientation: Hong Kong vs. United States students. Teach. Bus. Ethics 2000, 4, 151-167. [CrossRef]

75. Triandis, H.C.; Bontempo, R.; Villareal, M.J.; Asai, M.; Lucca, N. Individualism and Collectivism: Cross-Cultural Perspectives on Self-Ingroup Relationships. J. Personal. Soc. Psychol. 1988, 54, 323-338. [CrossRef]

76. Aguilera, R.V.; Rupp, D.E.; Williams, C.A.; Ganapathi, J. Putting the S back in corporate social responsibility: A multilevel theory of social change in organizations. Acad. Manag. Rev. 2007, 32, 836-863. [CrossRef]

77. Olkkonen, M.-E.; Lipponen, J. Relationships between organizational justice, identification with organization and work unit, and group-related outcomes. Organ. Behav. Hum. Decis. Process. 2006, 100, 202-215. [CrossRef]

78. Glavas, A.; Kelley, K. The effects of perceived corporate social responsibility on employee attitudes. Bus. Ethics Q. 2014, 24, 165-202. [CrossRef]

79. De Roeck, K.; Marique, G.; Stinglhamber, F.; Swaen, V. Understanding employees' responses to corporate social responsibility: Mediating roles of overall justice and organisational identification. Int. J. Hum. Resour. Manag. 2014, 25, 91-112. [CrossRef]

80. Branco, M.C.; Rodrigues, L.L. Corporate social responsibility and resource-based perspectives. J. Bus. Ethics 2006, 69, 111-132. [CrossRef]

81. Rupp, D.E.; Shao, R.; Thornton, M.A.; Skarlicki, D.P. Applicants' and employees' reactions to corporate social responsibility: The moderating effects of first-party justice perceptions and moral identity. Pers. Psychol. 2013, 66, 895-933. [CrossRef]

82. Abdul, Z.; Ibrahim, S. Executive and management attitudes towards corporate social responsibility in Malaysia. Corp. Gov. Int. J. Bus. Soc. 2002, 2, 10-16. [CrossRef]

83. Skouloudis, A.; Evangelinos, K.; Malesios, C. Priorities and perceptions for corporate social responsibility: An NGO perspective. Corp. Soc. Responsib. Environ. Manag. 2015, 22, 95-112. [CrossRef]

(C) 2019 by the authors. Licensee MDPI, Basel, Switzerland. This article is an open access article distributed under the terms and conditions of the Creative Commons Attribution (CC BY) license (http://creativecommons.org/licenses/by/4.0/). 